\title{
Association of the rs2279744 Promoter Polymorphism in the MDM2 Gene with Breast Cancer in a Mexican Population
}

María Guadalupe Márquez-Rosales ${ }^{1,2}$, José Sánchez-Corona1, Luis Eduardo Figuera ${ }^{3}$, Héctor Montoya-Fuentes ${ }^{1}$, Guillermo Moisés ZúñigaGonzález ${ }^{1}$, Ana María Puebla-Pérez ${ }^{4}$ and Martha Patricia Gallegos-Arreola ${ }^{3 *}$

${ }^{1}$ Molecular Medicine Division, Western Biomedical Research Center, Western National Medical Center, Mexican Institute of Social Security, Guadalajara, Jalisco, Mexico ${ }^{2}$ Health Sciences University Center, University of Guadalajara, Guadalajara, Jalisco, Mexico

${ }^{3}$ Genetics Division, Western Biomedical Research Center, Western National Medical Center, Guadalajara, Jalisco, México

${ }^{4}$ Inmmunopharmacology Laboratory, Exact and Engineering Sciences University Center, University of Guadalajara, Guadalajara, Jalisco, México

\section{Abstract}

Introduction: The MDM2 gene plays an important role as negative regulator of the p53 tumor suppressor. Data on polymorphisms in the MDM2 gene have revealed associations with cancer, particularly for the rs2279744 promoter polymorphism (309 T > G), which attenuates the P53 pathway and promotes tumorigenesis in the mammary gland.

Material and Methods: We examined the role of the MDM2 $309 \mathrm{~T}>\mathrm{G}$ polymorphism through a comparison of the genotypes of 408 healthy Mexican women with those of 529 Mexican women with breast cancer (BC).

Results: The genotype frequencies of the MDM2 $309 \mathrm{~T}>\mathrm{G}$ polymorphism in controls and BC patients were $25 \%$ and $23 \%$ for $\mathrm{T} / \mathrm{T}$ (wild type), $50 \%$ in $\mathrm{BC}$ and controls for $\mathrm{T} / \mathrm{G}$, and 25 and $27 \%$ for $\mathrm{G} / \mathrm{G}$ (polymorphic type), respectively. The obtained odds ratio (OR) was 1.07 , with a $95 \%$ confidence interval $(95 \% \mathrm{Cl})$ of $0.79-1.45, \mathrm{p}=0.64$ for the T/G$\mathrm{G} / \mathrm{G}$ genotypes. The association was evident when the distributions of the $\mathrm{G} / \mathrm{G}$ genotypes in patients exhibiting the following characteristics were compared: breastfeeding $>6$ months (OR 2.1, 95\% Cl 1.3-3.4, $p=0.002$ ), obesity (OR $1.8,95 \% \mathrm{Cl} 1.2-2.7, \mathrm{p}=0.003$ ) and high GGT levels (OR 1.7, 95\% Cl 1.1-2.5, $\mathrm{p}=0.012$ ). The genotype $\mathrm{G} / \mathrm{G}$ of the MDM2 309 T > G.

Conclusions: The MDM2 309 T > G polymorphism was associated with BC susceptibility, particularity in breastfeeding, obesity and high GGT levels in the analyzed Mexican population.

Keywords: Rs2279744; MDM2; Polymorphism; Breast cancer; Mexican population

\section{Introduction}

Between the developing countries of the world, breast cancer (BC) is a one of the most common diseases and is considered a public health problem [1]. The incidence rates of cancer vary in different ethnic groups [2]. In Mexico, BC is one of the five highest causes of death in women $>25$ years old [3], with an incidence of 15 per 100,000 Mexican women [4]. This statistic has increased within the last 7 years, and it is now one of the main causes of death among working-aged women [5]. A study of cancer incidence projection to 2030 conducted in Mexico estimates approximately 13,981 new cases per year, in which $38 \%$ of the women were $>68$ years old [6]. BC is considered a multifactorial disease, potentially resulting from a combination of abnormal gene interactions and environmental factors $[7,8]$. Therefore, the elucidation of genetic variants among different ethnic groups might contribute to explaining the progression of cancer and the chemotherapy response.

The mouse double minute 2 (MDM2) gene homolog or the E3 ubiquitin-protein ligase MDM2 gene is located on chromosome 12q15, comprising twelve exons. This gene encodes a protein of 491 amino acids that contains several conserved structural domains, including an $\mathrm{N}$-terminal p53 interaction domain, a central acidic domain, a Zinc finger domain and a C-terminal RING domain. The RING domain confers E3 ubiquitin ligase activity and is sufficient for E3 ligase activity in Mdm2 RING auto ubiquitination. The MDM2 protein functions as a negative regulator of p53 tumor suppressor activity and an E3 ubiquitin ligase for p53 degradation and possesses several binding sites for other tumor suppressors. The increased MDM2 expression in tumors suggests that the levels of MDM2 inactivate the apoptotic and cell cycle arrest functions of the $\mathrm{p} 53$ tumor suppressor, similar to the deletion or mutation of p53, common events observed in tumors [9].

The MDM2 gene exhibits several reported polymorphisms, one of which is rs2279744, a single nucleotide polymorphism in the first intron that increases MDM2 expression 2- to 3-fold. It has been suggested that the $\mathrm{G} / \mathrm{G}$ polymorphism might enhance promoter recognition through the transcription factor Sp1, which in turn elevates MDM2 expression and attenuates the p53-mediated apoptotic response to cellular stresses, including DNA damage [10].

Thus, polymorphisms in the MDM2 gene might impair the function of the p53-mediated stress response. Some studies have demonstrated the overexpression of MDM2 in human tumors, associated with poor prognosis [11,12]; however, other studies have not shown evidence of these associations [13-18]. Because the evidence is contradictory, the aim of the present study was to determine whether there is an association between the rs 2279744 polymorphism in the MDM2 gene and $\mathrm{BC}$ in Mexican women.

\section{Materials and Methods}

DNA was extracted from peripheral blood leukocytes in blood samples obtained from 408 healthy women recruited as volunteer blood donors using standard protocols [19]. These volunteers were not matched by age with the patient group. Blood samples were also collected from 529 patients with a clinical and histological diagnosis of

*Corresponding author: Martha Patricia Gallegos Arreola, Division of Genetics, CIBO IMSS, Sierra Mojada 800, Col. Independencia, Guadalajara, Jalisco 44340, México, Tel: +523336170060 Extn: 31936; E-mail: marthapatriciagallegos08@gmail.com

Received December 24, 2015; Accepted March 17, 2016; Published March 21 , 2016

Citation: Márquez-Rosales MG, Sánchez-Corona J, Figuera LE, Montoya- Fuentes H, Zúñiga-González GM, et al. (2016) Association of the rs2279744 Promoter Polymorphism in the MDM2 Gene with Breast Cancer in a Mexican Population (DSD) Reulting in Female Sex Reversal in 46XY Males. Hereditary Genet 5: 165. doi:10.4172/2161 1041.1000165

Copyright: (c) 2016 Márquez-Rosales MG, et al. This is an open-access article distributed under the terms of the Creative Commons Attribution License, which permits unrestricted use, distribution, and reproduction in any medium, provided the original author and source are credited. 
Citation: Márquez-Rosales MG, Sánchez-Corona J, Figuera LE, Montoya- Fuentes H, Zúñiga-González GM, et al. (2016) Association of the rs2279744 Promoter Polymorphism in the MDM2 Gene with Breast Cancer in a Mexican Population (DSD) Reulting in Female Sex Reversal in 46XY Males. Hereditary Genet 5: 165. doi:10.4172/2161 1041.1000165

Page 2 of 5

BC from June 2010 to May 2015. All individuals included in the present study were residents of the metropolitan area of Guadalajara. All samples were obtained after written informed was provided, and this study was previously approved through ethical committee 1305 of the Centro de Investigación Biomédica de Occidente, Instituto Mexicano del Seguro Social (IMSS). This study was conducted according to national and international ethical standards. The clinical and demographic data were obtained using written questionnaires. All of the patients were also interviewed to determine the occupational exposure and the use of pharmacological therapies. The BC patient database and patient DNA samples were examined for other polymorphisms [7,8,20-23].

The amplification of the rs2279744 polymorphism in the MDM2 gene was performed via PCR using the following primers: 5'-GAT TTC GGA CGG CTC TCG CGG C-3' and 5'-CAT CCG GAC CTC CCG CGC TG -3' [24]. The PCR amplifications were performed in a total volume of $15 \mu \mathrm{L}$ containing $0.2 \mathrm{mM}$ dNTPs (Invitrogen, Carlsbad, CA USA), 5 pmol of primers, $2.0 \mathrm{mM} \mathrm{MgCl}, 10 \% \mathrm{BSA}, 2.5 \mathrm{U}$ of Taq polymerase (Invitrogen, Carlsbad, CA USA), and $50 \mathrm{ng}$ of genomic DNA. The following PCR conditions were used: $95^{\circ} \mathrm{C}(4 \mathrm{~min})$, followed by $35 \mathrm{cycles}$ at $95^{\circ} \mathrm{C}(40 \mathrm{sec}), 58^{\circ} \mathrm{C}(40 \mathrm{sec})$ and $72^{\circ} \mathrm{C}(50 \mathrm{sec})$, with a final extension at $72^{\circ} \mathrm{C}(7 \mathrm{~min})$. Using this procedure, two fragments of 178 and $479 \mathrm{bp}$ were obtained. To facilitate allelic discrimination, the amplified products were separated on $8 \%$ polyacrylamide gels (19:1), followed by silver staining [25]. We determined that the $121 \mathrm{bp}$ fragment alone represented the wild-type genotype (T/T), while the 121, 104 and $17 \mathrm{bp}$ fragments indicated the heterozygous genotype $(\mathrm{T} / \mathrm{G})$, and the 104 and $17 \mathrm{bp}$ fragments represented the homozygous polymorphic genotype $(\mathrm{G} / \mathrm{G})$.

The allele frequencies were obtained through direct counting. The Hardy-Weinberg equilibrium was tested using a goodness-of-fit Chi square test to compare the observed genotype frequencies with the expected frequencies among control subjects. Odds ratios and 95\% confidence intervals (CI) were also calculated. A two-sided $\mathrm{p}<0.05$ was considered statistically significant. All statistical analyses were performed using PASW Statistic Base 18 software, 2009 (Chicago, IL).

\section{Results}

The comparative epidemiological data from $\mathrm{BC}$ patients and control individuals are shown in Table 1 . In the patient group, the average age was 54.36 years, ranging from 17 to 89 years. Menarche

\begin{tabular}{|c|c|c|c|c|c|}
\hline \multicolumn{3}{|c|}{ BC patients $^{(n=529)}$} & \multicolumn{2}{|c|}{ Controls $^{(n=408)}$} & \multirow{2}{*}{$\begin{array}{c}\begin{array}{c}\text { OR (IC } \\
\text { 95\%)* } \\
\boldsymbol{p} \text {-value }\end{array} \\
<0.0001\end{array}$} \\
\hline $\begin{array}{l}\text { Age (years) } \\
\text { Mean (SD) }\end{array}$ & 54.36 & $(11.51)$ & 46.14 & $(14.64)$ & \\
\hline \multirow[t]{2}{*}{$\begin{array}{l}\text { Menarche (years) } \\
\text { Mean (SD) }\end{array}$} & 12.57 & $(1.63)$ & 12.30 & $(0.82)$ & $<0.0001$ \\
\hline & \multicolumn{2}{|c|}{ (n) $\%$} & \multicolumn{2}{|c|}{ (n) $\%$} & \\
\hline \multicolumn{6}{|l|}{ Menarche (range) } \\
\hline $\begin{array}{l}7-10 \\
11-13 \\
14-18\end{array}$ & $\begin{array}{c}(41) \\
(337) \\
(151)\end{array}$ & $\begin{array}{c}8 \\
64 \\
28\end{array}$ & $\begin{array}{c}(0) \\
(302) \\
(106)\end{array}$ & $\begin{array}{c}0 \\
74 \\
26\end{array}$ & $\begin{array}{l}\text { NS } \\
\text { NS }\end{array}$ \\
\hline \multicolumn{6}{|c|}{ Tobacco Consumption } \\
\hline \begin{tabular}{|l} 
Yes \\
No
\end{tabular} & $\begin{array}{l}(148) \\
(381)\end{array}$ & $\begin{array}{l}28 \\
72\end{array}$ & $\begin{array}{l}(102) \\
(306)\end{array}$ & $\begin{array}{l}25 \\
75\end{array}$ & NS \\
\hline \multicolumn{6}{|c|}{ Alcohol Consumption } \\
\hline $\begin{array}{l}\text { Yes } \\
\text { No }\end{array}$ & $\begin{array}{l}(87) \\
(442)\end{array}$ & $\begin{array}{l}16 \\
84\end{array}$ & $\begin{array}{l}(82) \\
(326)\end{array}$ & $\begin{array}{l}20 \\
80\end{array}$ & NS \\
\hline
\end{tabular}

SD: standard deviation, NS: no significant difference, *OR (odds ratio) from the adjusted regression analysis.

Table 1: Demographic data for the study group.

\begin{tabular}{|c|c|c|c|c|c|}
\hline & (n) & $\%$ & & (n) & $\%$ \\
\hline Familial history (FH) & & & Histology & & \\
\hline No & (167) & 28 & Ductal & (472) & 89 \\
\hline $\mathrm{BC}$ & (73) & 13 & Lobular & (48) & 9 \\
\hline DM2-AH & (132) & 24 & Mixed & (9) & 2 \\
\hline DM2-AH-cancer* & (196) & 35 & Tumor stage & & \\
\hline Personal medical history & & & I-II & (181) & 34 \\
\hline No & (227) & 42 & III-IV & (348) & 66 \\
\hline DM-AH & (134) & 25 & $\begin{array}{l}\text { Lymph node } \\
\text { status }\end{array}$ & & \\
\hline $\begin{array}{l}\text { Breast fibrosis, } \\
\text { myomatosis, hysterectomy }\end{array}$ & (154) & 29 & Yes & (375) & 71 \\
\hline $\begin{array}{l}\text { Depression, pregnancy, } \\
\text { asthma }\end{array}$ & $(14)$ & 4 & No & (154) & 29 \\
\hline Body mass Index $(\mathrm{BMI})^{\star *}$ & & & Metastasis & & \\
\hline 18.5-24.9 (normal) & (100) & 19 & Yes & (181) & 32 \\
\hline 225-29.9 (overweight) & (185) & 35 & No & (377) & 68 \\
\hline 230-34.9 (obesity I) & (151) & 28 & $\begin{array}{l}\text { Chemotherapy } \\
\text { response }\end{array}$ & & \\
\hline$\geq 35$ (obesity II- IV) & (93) & 18 & Yes & (316) & 60 \\
\hline Tumor localization & & & No & (213) & 40 \\
\hline Unilateral & (501) & 95 & & & \\
\hline Bilateral & $(28)$ & 5 & Laboratory test & & \\
\hline Diagnostic time & & & $\begin{array}{l}\text { Hemoglobin }(\mathbf{g} / \\
\mathrm{dL})\end{array}$ & & \\
\hline $1-4$ years & $(406)$ & 77 & Mean (SD) & 13.01 & $(5.81)$ \\
\hline 5 - 9 years & (95) & 18 & Hematocrit (\%) & & \\
\hline $10-15$ years & $(28)$ & 5 & Mean (SD) & 37.29 & (4.14) \\
\hline Tumor markers & & & Platelets $\left(\mathbf{m m}^{3}\right)$ & & \\
\hline Luminal A & (255) & 43 & Mean (SD) & 360.45 & $(149.02)$ \\
\hline Luminal B & (104) & 20 & SGOT ( $\mu \mathrm{l} / \mathrm{L})$ & & \\
\hline Her2/neu & $(68)$ & 12 & Mean (SD) & 38.14 & (52.31) \\
\hline \multirow[t]{2}{*}{ Basal } & (102) & 25 & SGPT ( $\mu \mathrm{I} / \mathrm{L})$ & & \\
\hline & & & Mean (SD) & 40.09 & (45.37) \\
\hline No & (239) & 45 & LDH $(\mu \mathrm{I} / \mathrm{L})$ & & \\
\hline KI67 & (167) & 32 & Mean (SD) & 544.89 & (571.89) \\
\hline TP53 & (47) & 9 & $\operatorname{ALP}(\boldsymbol{\mu l} / \mathrm{L})$ & & \\
\hline \multirow[t]{3}{*}{ E-cadherin } & $(76)$ & 14 & Mean (SD) & 106.10 & (68.82) \\
\hline & & & GGT $(\mu \mathrm{I} / \mathrm{L})$ & & \\
\hline & & & Mean (SD) & 68.48 & (192.81) \\
\hline
\end{tabular}

*Positive familial history of cancer and leukemia in first and second degree relatives of patients. Transaminase (SGOT), Glutamic pyruvic transaminase (SGPT), Lactate dehydrogenase (LDH), Alkaline phosphatase (ALP), Gamma glutamyl transferase (GGT) ${ }^{\star *}$ according to OMS classifications. (Appropriate bodymass index for Asian populations and its implications for policy and intervention strategies. Ginebra (Suiza): World Health Organization, 2004).

Table 2: Clinical data from patients with $\mathrm{BC}$

presented at a mean age of 12.57 years in patients and 12.30 years in control individuals.

Table 2 shows the general clinical characteristics of the patient group. We observed that $24 \%$ of the patients exhibited diabetes mellitus (DM)-arterial hypertension (AH), 29\% of the patients presented breast fibrosis-myomatosis-hysterectomy, $43 \%$ of the patients were luminal A type, $89 \%$ of the patients displayed ductal histology, and $66 \%$ of the patients exhibited stage III-IV tumors.

The genotype and allele frequencies of the rs 2279744 polymorphism in the MDM2 gene were similar between control and patient groups ( $\mathrm{p}$ $>0.05$ ) (Table 3). The genotype distribution in the control group was in Hardy-Weinberg equilibrium and showed a marker informativity of 0.50 considered as moderately informative. All of the samples were analyzed, and the genotypes (for 408 controls and 529 BC patients) were obtained for all participants. 
Citation: Márquez-Rosales MG, Sánchez-Corona J, Figuera LE, Montoya- Fuentes H, Zúñiga-González GM, et al. (2016) Association of the rs2279744 Promoter Polymorphism in the MDM2 Gene with Breast Cancer in a Mexican Population (DSD) Reulting in Female Sex Reversal in 46XY Males. Hereditary Genet 5: 165. doi:10.4172/2161 1041.1000165

Page 3 of 5

\begin{tabular}{|c|c|c|c|c|c|c|c|}
\hline \multirow[b]{3}{*}{ 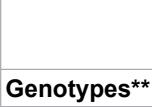 } & \multicolumn{4}{|c|}{ Groups } & \multirow{2}{*}{\multicolumn{3}{|c|}{ Patients vs. Controls }} \\
\hline & \multicolumn{2}{|c|}{ Patients $_{(529)}$} & \multicolumn{2}{|c|}{ Controls $_{(408)^{*}}$} & & & \\
\hline & (n) & $\%$ & (n) & $\%$ & OR & $\mathrm{Cl} 195 \%$ & p value \\
\hline$T / T$ & $(124)$ & 23 & (101) & 25 & 1 & & \\
\hline$T / G$ & (263) & 50 & (205) & 50 & 0.97 & $(0.75-1.26)$ & 0.87 \\
\hline$G / G$ & (142) & 27 & (102) & 25 & 1.10 & $(0.81-1.47)$ & 0.52 \\
\hline$T / G$ and $G / G$ & $(405)$ & 77 & (307) & 75 & 1.07 & $(0.79-1.45)$ & 0.64 \\
\hline \multicolumn{8}{|l|}{ Alleles } \\
\hline$T$ & (511) & 0.4829 & 3) & 0.4987 & 0.93 & $(0.78-1.12)$ & 0.49 \\
\hline G & (547) & 0.5171 & (409) & 0.5013 & 1.06 & $(0.88-1.27)$ & 0.49 \\
\hline
\end{tabular}

*Hardy-Weinberg equilibrium in controls (chi-square test $=0.0098 ; p=0.92103$ ). ** Marker informativity of 0.50 assessed within a range of $0-1$ : markers with a score higher than 0.7 were considered highly informative, whereas markers with a value of 0.44 were considered moderately informative [7-8, 20-23].

Table 3: The genotype distribution of the rs2279744 promoter polymorphism in $M D M 2$ in $\mathrm{BC}$ patients and healthy controls.

\begin{tabular}{|l|c|c|c|c|c|c|c|c|}
\hline & \multicolumn{7}{|c|}{$95 \%$ Cl } \\
\hline & B & SD & Wald & Df & $\boldsymbol{P}$ & OR & Low & Upper \\
\hline $\begin{array}{l}\text { Breast- } \\
\text { feeding }(<6 \\
\text { month) }\end{array}$ & 0.750 & 0.242 & 9.575 & 1 & 0.002 & 2.116 & 1.316 & 3.402 \\
\hline Obesity & 0.610 & 0.207 & 8.711 & 1 & 0.003 & 1.840 & 1.227 & 2.757 \\
\hline GGT & 0.532 & 0.212 & 6.302 & 1 & 0.012 & 1.703 & 1.124 & 2.581 \\
\hline Constant & -1.622 & 0.168 & 93.111 & 1 & 0.000 & 0.197 & & \\
\hline
\end{tabular}

Variables included in the analysis: dependent: BC patients classified by the $G / G$ genotype.

Table 4: The associations of the rs2279744 promoter polymorphism in MDM2 with more than one variable among the general characteristics of $\mathrm{BC}$ patients.

Table 4 shows that the G/G genotype was associated with breastfeeding ( $<6$ month) (OR 2.11, 95\% CI 1.31-3.40, p = 0.002), obesity (OR $1.8,95 \%$ CI 1.22-2.75, $\mathrm{p}=0.003)$ and higher GGT levels (OR 1.7, 95\% CI $1.12-2.58, \mathrm{p}=0.012$ ) as risk factors.

The data obtained from the survival analysis using the KaplanMeier method showed that differences in the diagnosis period and age of $B C$ in patients with $G / G$ genotypes were not statistically significant (log-rank test, $\mathrm{p}=0.914)$ (data not shown).

\section{Discussion}

$\mathrm{BC}$ is a multifactorial disease with a complex etiology and is considered a major public health problem in industrialized countries. In Mexico, BC it is currently one of the leading causes of death in working-aged women [2, 5,7,8,20-23]. These facts are consistent with the observations in the present study and other studies, where the average age of BC patients was $54.36( \pm 11.51$ years $)$ and was found to be a risk factor. Multiple studies have previously observed these associations $[1,2,5,26]$.

Gene polymorphisms with a low penetrance are risk factors in $\mathrm{BC}$ $[2,5,7,8,17-23,27]$.

The genetic regulation of MDM2 in P53 tumor suppressor activity in cancer has been the focus of many investigations. MDM2 has been proposed as a negative regulator of the P53 tumor suppressor pathway, influencing the binding of MDM2 to P53, thereby inhibiting the activity of this protein, resulting in the degradation of this tumor suppressor via the ubiquitination pathway [28]. The presence of the rs2279744 polymorphism in the promoter region up-regulates the expression of MDM2 through affinity for the SP1 transcription factor, inhibits the transcription of $\mathrm{p} 53$ activity, induces tumor promotion in the mammary gland and might impact $\mathrm{BC}$ oncogenesis. This polymorphism has been extensively studied in relation to many types of cancers, including $\mathrm{BC}$
[28-30]. However, findings from these studies have been inconsistent [13-18].

Furthermore, the data obtained in the present study also showed that the genotype distribution of the rs2279744 MDM2 polymorphism followed Hardy-Weinberg equilibrium $(P>0.05)$. The genotype $G / G$ frequencies (25\%) of the rs2279744 polymorphism in the control group were similar to those previously reported in Indian (28\%) [12], Chinese (25.8\%) [31], and Turkish populations (29.6\%) [32]. Several authors have studied the MDM2 $309 \mathrm{~T}>\mathrm{G}$ polymorphism, although these studies did not analyze the same markers, and the studied groups have had different compositions (e.g., regarding female, male, menopause, tumor stages, ethnic backgrounds, and ages). Consequently, there are conflicting results regarding this association, with several studies observing a decreased risk of $\mathrm{BC}$ in association with the MDM2 $309 \mathrm{~T}>\mathrm{G}$ polymorphism [13-18,33]. We observed similar genotype frequencies of the $\mathrm{G} / \mathrm{G}$ polymorphism in the control and $\mathrm{BC}$ groups $(\mathrm{P}$ $>0.05$ ). Singh et al. [34] did not observe an association of the MDM2 $309 \mathrm{~T}>\mathrm{G}$ polymorphism with $\mathrm{BC}$ in a study of $104 \mathrm{BC}$ patients and 105 controls from the Indian population. In addition, Schmidt et al. (2007 and 2009) [13,14] did not observe an association of the MDM2 $309 \mathrm{~T}>$ $\mathrm{G}$ polymorphism with breast cancer risk and age at the onset of breast cancer in a pooled series of 5,191 cases and 3,834 controls from the Breast Cancer Association Consortium (BCAC). Cox et al. [15] did not observe a risk association of the MDM2 $309 \mathrm{~T}>\mathrm{G}$ polymorphism with breast cancer in a study on the health of nurses. Other studies have also shown no evidence of this association [16-19].

In the present study, we also observed an association of the $\mathrm{G} / \mathrm{G}$ genotype as a risk factor in $\mathrm{BC}$ patients, showing breastfeeding $>6$ months, obesity (BMI 25-29.9) and high GGT plasma levels. The relationship between breastfeeding, obesity and $\mathrm{BC}$ is complex and has been associated with factors including genetic predisposition, social class, exercise, alcohol consumption and diet [7-8,21-23]. The data obtained from 47 epidemiological studies in 30 countries, including 50302 women with invasive breast cancer and 96973 controls, reported that women who breast feed longer are more protected against breast cancer, and the lack of or short duration of breastfeeding typical of women in developed countries primarily contributes to the high incidence of breast cancer in these countries [34].

Parkin [35] observed that approximately $3 \%$ of BC patients from UK were associated with breastfeeding for less than 6 months. One potential explication of the data observed in the present study is that the risk effect could reflect factors that inhibit the induction of the differentiation of the mammary epithelium, making this tissue more susceptible to environmental carcinogens, and the stimulation of ovulatory cycles through prolonged time with hormonal effects in different pathways, such as MDM2 and TP53, thereby promoting tumorigenesis [36].

The results observed in the present study with respect to obesity most likely reflect both prolonged exposure to estrogens and nutritional status. Several studies have also observed that obesity is associated with an increased risk of developing BC [7,21,37]. Esfahlan et al. [38] suggested that obesity could play a significant role in estrogen receptor gene expression, affecting the progression and proliferation of $\mathrm{BC}$ cells. It has also been suggested that the aromatization of estrogen and androgens is higher in obese postmenopausal women, and this increase could stimulate tumor growth and adversely affect the patient prognosis $[7,39]$. In addition, some genetic factors have been implicated in the association of obesity with cancer, such as the stability of the p53MDM2 interaction, including posttranslational modifications of $\mathrm{p} 53$. 
Citation: Márquez-Rosales MG, Sánchez-Corona J, Figuera LE, Montoya- Fuentes H, Zúñiga-González GM, et al. (2016) Association of the rs2279744 Promoter Polymorphism in the MDM2 Gene with Breast Cancer in a Mexican Population (DSD) Reulting in Female Sex Reversal in 46XY Males. Hereditary Genet 5: 165. doi:10.4172/2161 1041.1000165

Page 4 of 5

Studies on obese rodents fed high-fat, high-sucrose diets suggest that tumor suppressor p53 modifications might play a role in obesity [40,41]. Other studies have shown that the high concentration of hepatic p53 is provocative for conditions of obesity or fatty liver, playing a role in regulation through MDM2-p53 and contributing to the development of tumorigenesis [40-42]. Although the precise mechanisms underlying the relationship between the regulation of MDM2 to p53 and obesity remain unclear, studies have shown that p53 gene is activated in the adipocytes of ob/ob mice, functioning in the mechanisms of dysregulated gene expression in the adipose tissue of obese animals, and MDM2, as a negative regulator of p53, also participates in the dysregulated gene expression in adipose tissues and participates in the promotion of BC tumorigenesis [41,42].

We also observed an association of the $\mathrm{G} / \mathrm{G}$ genotypes of $\mathrm{BC}$ patients with elevated levels of GGT as a risk factor. However, there are no available studies addressing the influence of the $G / G$ genotype of the MDM2 gene and the high levels of GGT in BC patients. This observation could likely reflect the participation of GGT in cellular glutathione metabolism, cell proliferation, apoptosis, tumor progression, invasion and cancer cell drug resistance. The expression of GGT is often increased in tumors and has been suggested as a biomarker [8,43-45]. The GGT enzyme is constitutively expressed in various organs, and this expression is significantly elevated in premalignant lesions or malignant tumors; therefore, GGT is considered to confer a favorable environment for the growth and survival of neoplastic cells $[44,46]$. An increased level of GGT has been associated with higher rates of DNA damage and different cancers [45-47]. Previous studies have shown associations between cell surface GGT and the tetraspan 4 family, including CD53, CD81 and CD82, as molecules that mediate the signal transduction involved in the modulation of cell responses [48]. Fentiman et al. suggested that premenopausal women with high serum or elevated levels of GGT are at increased risk of breast cancer and might benefit from close surveillance, potentially through breast magnetic resonance imaging. Serum GGT might indicate previous exposure to carcinogens and lead to the identification of DNA adducts involved in mammary carcinogenesis [44]. Thus, GGT could reflect previous exposure to as yet unknown carcinogens initiating breast carcinogenesis.

However, the regulation mechanism of MDM2-p53 likely influences the overexpression of GGT in BC, in addition to other factors, such as metastatic nodes, tumor markers, menopause, diagnosis period, tumor stage, obesity, and treatment resistance $[7,8,20]$. This response might be affected through polymorphisms in the MDM2 gene that can indirectly contribute to the modification of MDM2 activity, producing changes in DNA and subsequently participating in neoplastic progression.

Scott suggested that "genetic differences between individuals have been predicted to account for disparate outcomes in patients diagnosed with cancer. The search for genetic determinants has been ongoing for a considerable amount of time, and it is only now that insights have been gained into which polymorphisms are most likely to be important in determining not only disease likelihood but also outcome" [49].

\section{Conclusion}

The results of the present study revealed that the frequencies of the homozygous G/G genotype of the MDM2 $309 \mathrm{~T}>\mathrm{G}$ polymorphism were not significantly different between control and $\mathrm{BC}$ patients. However, the differences were most evident in patients breast feeding $>6$ months, exhibiting obesity, and exhibiting high levels of GGT, as risk factors that might significantly contribute to BC susceptibility in the analyzed sample from a Mexican population. Nevertheless, further studies are required to confirm or reject these observations.

\section{Competing Interests}

The authors report no financial conflicts of interest. The authors are responsible for the content and drafting of this manuscript.

\section{Author Contributions}

All of the authors contributed to the manuscript, the conception and design of the study and the acquisition, analysis and interpretation of the data.

\section{Acknowledgments}

The authors would like to thank Dr. Efrain Salas and the nurses from UMAE Hospital de Gineco-Obstetricia, CMNO, IMSS for facilitating sample collection. This research was financially supported in part through FIS/IMSS/PROT/G15/1463 grants.

\section{References}

1. Siegel R, Desantis C, Virgo K, Stein K, Mariotto A, et al. (2012) Cancer treatment and survivor ship statistics. CA Cancer J Clin 262: 220-241.

2. Miller J, King J, Joseph D, Richardson L (2012) Breast cancer screening among adult women - behavioral risk factor surveillance system, USA, 2010. MMWR Suppl 61: 46-50

3. Niëns L, Zelle S, Gutiérrez C, Rivera G, Hidalgo B, et al. (2014) Costeffectiveness of breast cancer control strategies in Central America: the cases of Costa Rica and Mexico. PLoS One 9: e95836.

4. Chávarri Y, St Louis J, Liedke P, Symecko H, Villarreal G, et al. (2014) Access to care issues adversely affects breast cancer patients in Mexico: oncologists perspective. BMC Cancer 14: 658.

5. Chávarri Y, Villarreal C, Liedke P, Knaul F, Mohar A, et al. (2012) Breast cance in Mexico: a growing challenge to health and the health system. Lancet Oncol 13: $335-343$

6. Aggarwal A, Unger K, Lewison G, Sullivan R (2015) The challenge of cancer in middle-income countries with an ageing population: Mexico as a case study. Ecancermedicalscience 9: 536

7. Gallegos M, Figuera L, Flores L, Puebla A, Zúñiga G (2015) Association of the Alu insertion polymorphism in the progesterone receptor gene with breast cancer in a Mexican population. Arch Med Sci 11: 551-560.

8. Gallegos M, Figuera L, Ramos A, Salas E, Puebla A, et al. (2014) The association between the 844ins68 polymorphism in the CBS gene and breast cancer. Arch Med Sci 10: 1214-1224.

9. Iwakuma T, Lozano G (2003) MDM2, an introduction. Mol Cancer Res 1: 9931000.

10. Fang Y, Kong B, Yang Q, Ma D, Qu X (2009) MDM2 309 polymorphism is associated with missed abortion. Hum Reprod 24: 1346-1349.

11. Inomistova M, Svergun N, Khranovska N, Skachkova O, Gorbach O, et al. (2015) In: Klymnyuk GI. (ed.) Prognostic significance of MDM2 gene expression in childhood neuroblastoma. Exp Oncol 37: 111-115.

12. Bhowmik A, Das S, Bhattacharjee A, Choudhury B, Naiding M, et al. (2015) MDM2 and TP53 polymorphisms as predictive markers for head and neck cancer in Northeast Indian population: Effect of gene-gene and geneenvironment interactions. Asian Pac J Cancer Prev 16: 5767-5772.

13. Schmidt MK, Reincke S, Broeks A, Braaf L, Hogervorst F, et al. (2007) Do MDM2 SNP309 and TP53 R72P interact in breast cancer susceptibility? A large pooled series from the breast cancer association consortium. Cancer Res 67 : 9584-9590.

14. Schmidt MK, Tommiska J, Broeks A, van Leeuwen F, Van't Veer L, et al. (2009) Combined effects of single nucleotide polymorphisms TP53 R72P and MDM2 SNP309, and p53 expression on survival of breast cancer patients. Breast Cancer Res 11: R89.

15. Cox DG, Deer D, Guo Q, Tworoger S, Hankinson S, et al. (2007) The p53 Arg72Pro and MDM2 -309 polymorphisms and risk of breast cancer in the nurses' health studies. Cancer Causes Control 18: 621-625.

16. Copson E, White H, Blaydes J, Robinson D, Johnson P, et al. (2006) Influence of the MDM2 single nucleotide polymorphism SNP309 on tumour development in BRCA1 mutation carriers. BMC Cancer 6: 80 . 
Citation: Márquez-Rosales MG, Sánchez-Corona J, Figuera LE, Montoya- Fuentes H, Zúñiga-González GM, et al. (2016) Association of the rs2279744 Promoter Polymorphism in the MDM2 Gene with Breast Cancer in a Mexican Population (DSD) Reulting in Female Sex Reversal in 46XY Males. Hereditary Genet 5: 165. doi:10.4172/2161 1041.1000165

17. Millikan R, Heard K, Winkel S, Hill E, Heard K, et al. (2006) No association between the MDM2 -309 T/G promoter polymorphism and breast cancer in African-Americans or Whites. Cancer Epidemiol Biomarkers Prev 15: 175-177.

18. Wilkening S, Bermejo J, Burwinkel B, Klaes R, Bartram C, et al. (2006) The single nucleotide polymorphism IVS1+309 in mouse double minute 2 does not affect risk of familial breast cancer. Cancer Res 66: 646-648.

19. Miller S, Dykes D, Polesky H (1988) A simple salting out procedure for extracting DNA from human nucleated cells. Nucleic Acids Res 6: 1215

20. Ramos A, Figuera L, Soto O, Puebla A, Ramírez R, et al. (2015) Association of the C677T polymorphism in the methylene tetrahydrofolate reductase gene with breast cancer in a Mexican population. Genet Mol Res 14: 4015-4026.

21. Gómez FL, Escoto-De A, Puebla A, Figuera L, Ramos A, et al. (2013) Association of the tumor necrosis factor-alpha $-308 \mathrm{G}>\mathrm{A}$ polymorphism with breast cancer in Mexican women. Genet Mol Res 12: 5680-5693.

22. Ramírez R, Figuera L, Puebla A, Delgado J, Legazpí M, et al. (2013) Intron 4 VNTR $(4 \mathrm{a} / \mathrm{b})$ polymorphism of the endothelial nitric oxide synthase gene is associated with breast cancer in Mexican women. J Korean Med Sci 28: 15871594

23. Soto O, Zúñiga G, Ramírez R, Ramos A, Figuera L, et al. (2015) Association of the GSTM1 null polymorphism with breast cancer in a Mexican population. Genet Mol Res 14: 13066-13075.

24. Amaral C, Cetkovská K, Gurgel A, Cardoso M, Chagas B, et al. (2014) MDM2 polymorphism associated with the development of cervical lesions in women infected with Human papillomavirus and using of oral contraceptives. Infect Agent Cancer 9: 24.

25. Sanguinetti C, Dias N, Simpson A (1994) Rapid silver staining and recovery of PCR products separated on polyacrylamide gels. Biotechniques 17: 914-921.

26. Li C, Yu C, Wang P (2015) An age-period-cohort analysis of female breast cancer mortality from 1990-2009 in China. Int J Equity Health 14: 76

27. Mojgan $H$, Massoud $H$, Ahmad E (2012) ERCC1 intron 1 was associated with breast cancer risk. Arch Med Sci 8: 655-658.

28. Peng Q, Mo C, Qin A, Lao X, Chen Z, et al. (2013) MDM2 SNP309 polymorphism contributes to endometrial cancer susceptibility: evidence from a meta-analysis. J Exp Clin Cancer Res 32: 85.

29. Knappskog S, Gansmo LB, Dibirova K, Metspalu A, Cybulski C, et al. (2014) Population distribution and ancestry of the cancer protective MDM2 SNP285 (rs117039649). Oncotarget 5: 8223-8234.

30. Sun YF, Leu JD, Chen SM, Lin IF, Lee YJ (2009) Results based on 124 cases of breast cancer and 97 controls from Taiwan suggest that the single nucleotide polymorphism (SNP309) in the MDM2 gene promoter is associated with earlier onset and increased risk of breast cancer. BMC Cancer 9: 13.

31. Wang X, Jin L, Cui J, Ma K, Chen X, et al. (2015) Mouse double minute-2 homolog (MDM2)-rs2279744 polymorphism associated with lung cancer risk in a Northeastern Chinese population. Thorac Cancer 6: 91-96.

32. Kafadar A, Küçükhüseyin Ö, Turan S, Yenilmez E, Tunoglu S, et al. (2015) Distribution and Effects of CDKN2 p16 $540 \mathrm{C}>\mathrm{G}$ and $580 \mathrm{C}>\mathrm{T}$, and MDM2 SNP309 T>GPolymorphisms in Patients with Primary Brain Tumors. Anticancer Res 35: 3933-3942.

33. Singh V, Rastogi N, Mathur N, Singh K, Singh MP (2008) Association of polymorphism in MDM-2 and p53 genes with breast cancer risk in Indian women. Ann Epidemiol 18: 48-57.

34. Collaborative Group on Hormonal Factors in Breast Cancer (2002) Breast cancer and breastfeeding: collaborative reanalysis of individual data from 47 epidemiological studies in 30 countries, including 50302 women with breast cancer and 96973 women without the disease. Lancet 360: 187-195.

35. Parkin DM (2011) Cancers attributable to reproductive factors in the UK in 2010. Br J Cancer 105: S73-S76.

36. Jerry D, Minter L, Becker K, Blackburn A (2002) Hormonal control of p53 and chemoprevention. Breast Cancer Res 4: 91-94.

37. Widschwendter P, Friedl T, Schwentner L, DeGregorio N, Jaeger B, et al (2015) The influence of obesity on survival in early, high-risk breast cancer: results from the randomized success a trial. Breast Cancer Res 17: 129.

38. Esfahlan R, Zarghami N, Esfahlan A, Mollazadeh M, Nejati K, et al. (2011) The possible impact of Obesity on androgen, progesterone and estrogen receptors (ER $\alpha$ and $E R \beta)$ Gene expression in breast cancer patients. Breast Cancer (Auckl) 5: 227-237.

39. Macciò A, Madeddu C (2011) Obesity, Inflammation, and Postmenopausal Breast Cancer: Therapeutic Implications. Scientific World Journal 11: 20202036.

40. Minamino T, Orimo M, Shimizu I, Kunieda T, Yokoyama M, et al. (2009) A crucia role for adipose tissue p53 in the regulation of insulin resistance. Nat Med 15 1082-1087.

41. Yahagi N, Shimano $H$, Matsuzaka T, Sekiya M, Najima $Y$, et al. (2004) p53 involvement in the pathogenesis of fatty liver disease. J Biol Chem 279: 2057120575.

42. Nelson L, Valentine R, Cacicedo J, Gauthier M, Ido Y, et al. (2012) A nove inverse relationship between metformin-triggered AMPK-SIRT1 signaling and p53 protein abundance in high glucose-exposed HepG2 cells. Am J Physio Cell Physiol 303: C4-C13.

43. Pompella A, De Tata V, Paolicchi A, Zunino F (2006) Expression of gammaglutamyltransferase in cancer cells and its significance in drug resistance. Biochem Pharmacol 71: 231-238.

44. Fentiman I, Allen D (2010) Gamma-glutamyl transferase and breast cancer risk. Br J Cancer 103: 90-93.

45. Strasak A, Pfeiffer R, Klenk J, Hilbe W, Oberaigner W, et al. (2008) Prospective study of the association of gamma-glutamyltransferase with cancer incidence in women. Int J Cancer 123:1902-1906.

46. Corti A, Duarte T, Giommarelli C, De Tata V, Paolicchi A, et al. (2009) Membrane gamma-glutamyl transferase activity promotes iron-dependent oxidative DNA damage in melanoma cells. Mutat Res 669: 112-121.

47. Dawson J, Smith G, Boak J, Peters T (1979) Gamma-Glutamyltransferase in human and mouse breast tumours. Clin Chim Acta 96: 37-42.

48. Bouman L, Sancéau J, Rouillard D, Bauvois B (2002) Gamma-Glutamyl transpeptidase expression in Ewing's sarcoma cells: up-regulation by interferons. Biochem J 364: 719-724.

49. Scott $R$ (2010) Have the roles of two functional polymorphisms in breast cancer, R72P in P53 and MDM2-309 in MDM2, become clearer? Breast Cancer Res 12: 102 